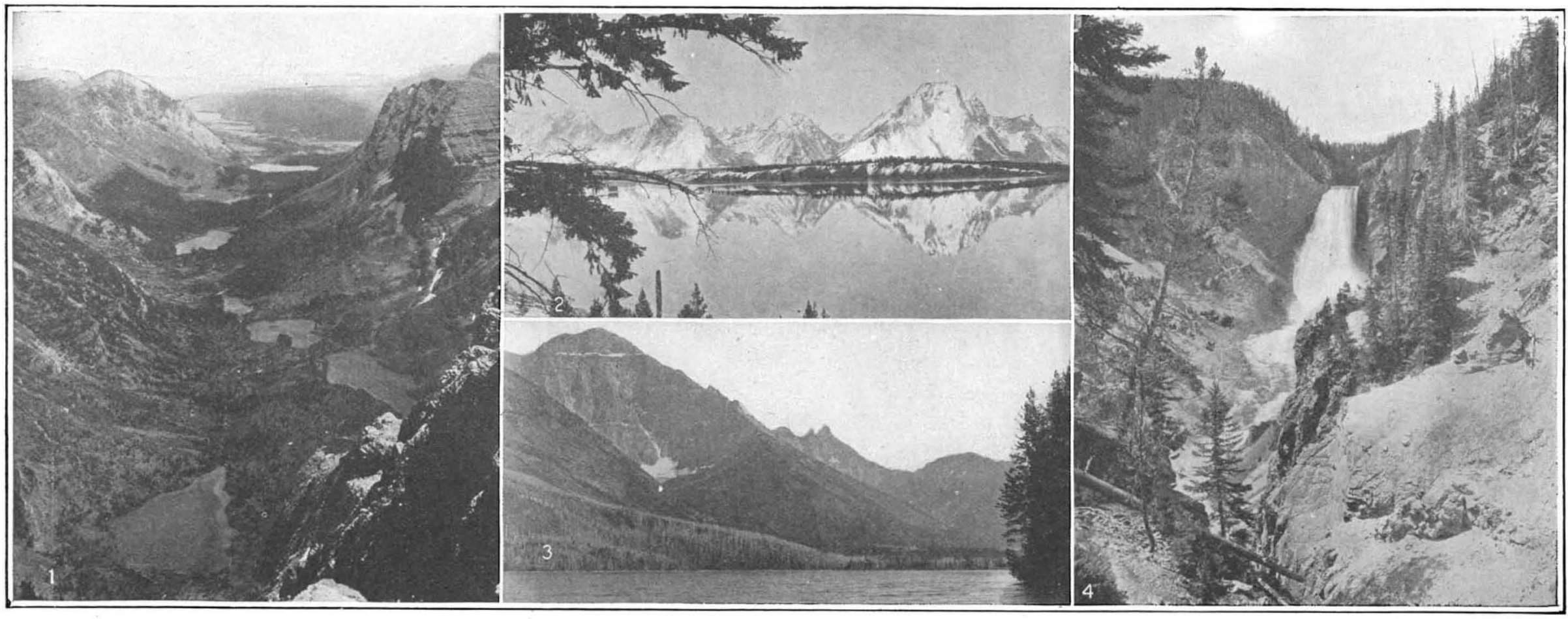

Lef!: Looking toward the plains Prom Swiftcurrent Peak in Glacier Park (J. E. Haynes). Center, Upper: The Teton Range, Wyoming, rises j,000 to 7,000 Peet above Jackson Lake (U. S. Reclamation Service). Center, Lower: Mt. Cleveland, 10,438 feet and Waterton Lake in the seldom visited northe
(Bailey Willis). Right: 'The Great Fall of the Ycllowstone (Copyright. J. E. Haynes).

What the camera has to report regarding the natural wonders of Montana and Wyoming

\title{
From the Mountains of Montana to the Tetons of Wyoming
}

\author{
Strolls Through a Region Whose Scenic Beauties Are Menaced by the Mailed Fist of Commercialism \\ By LeRoy Jeffers. F.R.G.S.
}

\begin{abstract}
W E entered Glacier Park, Montana, in the usual wall of Swiftcurrent Pass in search of Alpine flowers wall of Swiftcurrent Pass in search of Alpine flowers
and continued upward to the summit of Swiftcurrent Peak where there is a comprehensive view of the park. In ages past internal pressure has forced the very ancient and rarely exposed Algonkian strata to the very summit of these mountains and the landscape is enlirened with buff and gray limestone, green and dark red shale. From the rim of the Grand Canyon of the Colorado in Arizona one may look down for thousands of feet upon these strata, but here their position is reversed. Down the valley toward the plains there is a chain of blue lakes and, in the distant haze, the high ridges glow with soft pink. In other directions there a re a multitude of peaks and valleys with many small glaciers. Far to the north is Mt. Cleveland, 10,438 feet, the highest in the park. From Granite Park we visited the Garden Wall, which is the summit of the cirque of Grinnell Glacier. Along the way were colorful strata ranging from light blue-green to purplish red, while here and there touches of bright yellow were added by lichens. As we peered down upon the scarred and dirty surface of the glacier, over which the shadow of serrated peaks was traveling, we heard the roar of the stream on its way to Lakes Grinnell and Jusephine. Through the smoke of forest fires the slope of Mt. Allen glowed deep red and purple in the sunlight
\end{abstract}

Many enthusiastic writers have overcolored their descriptions of Glacier scenery, conveying the impression that the landscape is like the Grand Canyon. This is not the case, for color is distributed far more sparingly on these mountains and depends to a larger degree for its effect on the character of the light At eyening from the chalet we gazed into the north toward the highest mountains of the park and the distant valley of Waterton Lake which leads into Canada. Twilight had filled the deep valley beneath us; while bey ond were two long ridges slumbering in the blue haze. Piercing the horizon was a mountain, gray like the clouds above it. As the sun descended it filled the sky around this peak with deep crimson light, and turned the mountain into a volcano with crater of molten fire. Elsewhere in the light blue sky, goldentinted clouds became rosy in the afterglow.

Shouldering our packs at dawn, we started on the long trail for Waterton Lake At first, there was a steep descent of 2500 feet to Mineral Creek, through the towering pine, spruce, larch and fir which clothes the western slope of the range. There were glimpses of rosy peaks, of a blackened hanging glacier, and of little waterfalls on the Livingston Range. Some of the trees were fantastically but fatally draped with hanging moss which sooner or later will cause their death. From the floor of the valley we followed Minera Creek for miles, beneath the cliffs of Flattop Mountain, to the divide which separates the northern and southern waters of the great central valley of the park. There were carpets of ferns and thickets of huckleberries and red thimbleberries with now and then the thorny leaves and brilliant berries of the Devil's Club. Beyond the falls of Kipp Creek we ascended a high valley where all the trees had been broken off by a great wind. Nestling in every murmuring creek bed was a bower of Alpine flowers, pink and white and yellow, the home of countless happy butterflies and bees.

Climbing the steep slopes of the divide we rounded

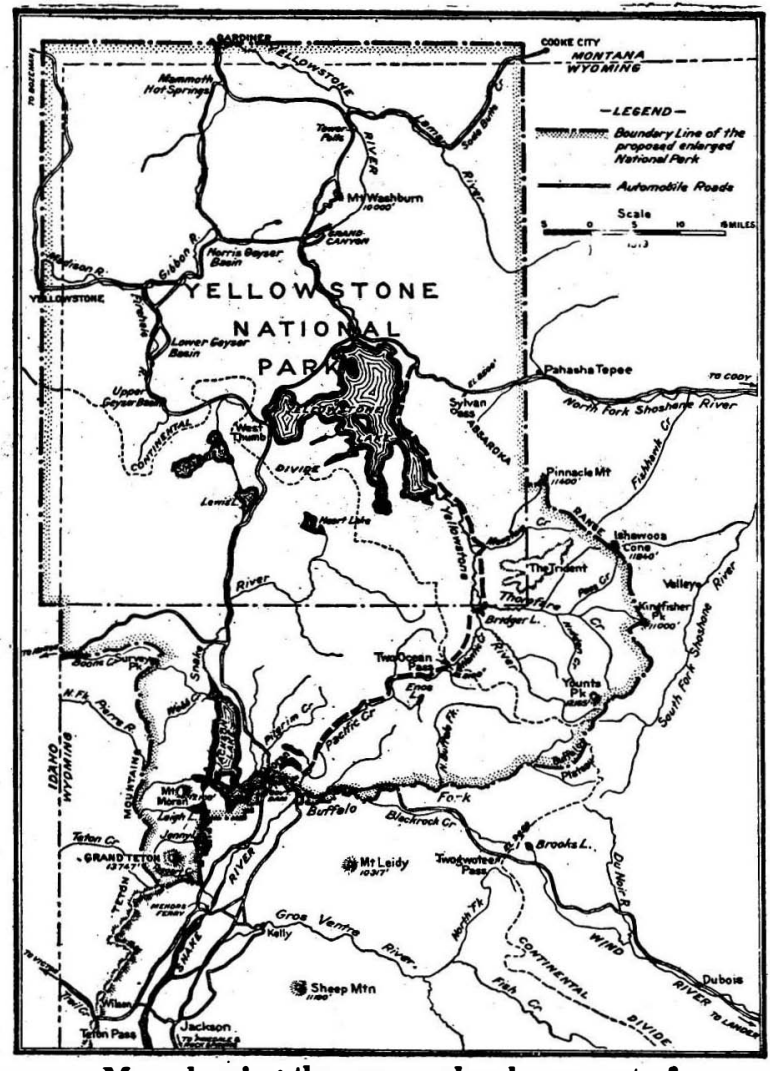

Map showing the proposed enlargement of Yellowstone Park the walls of Mt. Kipp, admiring the imposing architecture of Cathedral Peak which is most appropriately named. Deer were near at hand, bounding across the mountain meadows, as we approached. It was Augus and the first full glory of the flower fields had passed, but in these high Alpine gardens buttercups and sweetscented adder tongue were blooming close to the snowbanks. At last we overlooked the course of the Little Kootenay where ridge upon ridge and peak after peak crowded one upon another; then the trail plunged into Waterton Valley with delicious wild raspberries bordering the way. The rocky bed of the creek was deep red and green. strikingly contrasting with the foamin water, and we were impressed with the unusually sharp and curious pinnacles of the Citadel Peaks. After several miles of blood-thirsty mosquitoes whose ability I have not seen equalled this side of Alaska, we decided to spend the night in the shelter of an abandoned cabin. We had traveled over twenty mountain miles that day and were not far from the head of Waterton Lake.

In the morning we had a rugged view up Olson Creek toward Brown Pass and the famous Bowman and Kintla country. To the left was Porcupine Ridge and towering in the center was the imposing Sentinel. We had thought to visit this region, but the rapidly increasing smoke from forest fires hid the mountains from our view, and, after waiting for some hours on the shore of the lake, we continued for four miles to the Ranger's cabin on the left bank. After a rapic sail of five miles in a canoe we reached the hamlet of Waterton Lakes in Canada. Here is a beautiful view in clear, weather of the high mountains which cluster g round the head of the lake. It was forty miles by auto to Pincher on the Canadian Pacific, which we reached that night.

The Yellowstone

Scenically the most interesting approach to Yellow stone Park is from Cody by way of the Canyon of the North Fork of the Shoshone. As the gorge narrows its gray walls are tinged with pink and tower abruptly, forcing the road to climb through tunnels. $A$ dam 328 feet in height has been built at the head of the canyon, forming a lake ten miles in length. As we go on through the Shoshone Forest there are many eroded pinnacles of rock, the finest group being named "The Holy City," Through an opening high in the cliffs its towers and spires rise heavenward in impressive and satisfying harmony. After entering the park there is a fine forest of yellow pine, and beyond Sylvan Pass is (Continued on page 375 ) 
and heating purposes are now using a gasoline extraction plant through which the gas is run and have greatly increased their revenues.

In the eastern oil fields, the nautra gas has been turned into gasoline and many of the oil producers that wer about to sell their slowly declining oi production or abandon it altogether have been saved from this situation and are today making more money in a week from the sale of their gasoline than they make in a month from the sale of their oil production. The cost of a plant with al machinery is nominal, in spite of the de mand, and where millions of cubic feet of gas has been wasted by escaping or burning, it is now being turned into a steady income.

The industry is growing steadily and it is almost impossible to secure correct figures upon the present output. The writer is able to present but few com parisons for this reason. In 1916, one authority submitted figures showing that 65,364,665 gallons of casing-head gasoline were made which sold at an average price of $\$ .079$ a gallon with a total value of $\$ 5,150,838$. The same authority is re sponsible for the statement that one year later in January, 1917, the state of Okla homa had 95 casing-head gasoline plants with a daily production of 200,000 gallons This would mean a yearly production o $19,000,000$ gallons from one state alon and it is eertain that Kansas, Texas and other oil- and gas-producing states are making an equal, if not larger produc tion.

\section{Testing Paper by Tearing}

(Continued from page 359 )

which is much in the nature of a pendulum, is provided with an adjustable weight and is shown in the illustratio raised almost to the horizontal and supported by the framework.

The machine, as shown in the illustration, is ready for testing. All that is necessary is to release the pendulum an let it swing downward carrying with it the wheel and the wire, thus pulling the letter clip upward and tearing the sheet of paper. After the tearing has been completed the pendulum continues to swing to the other side and the total ar of swing is measured by means of the small pointer which will be noticed at the top of the wheel. The pendulum will not swing as high on the right side as in its original position on the left side and the difference between these two values is measure of the work required to tear the paper, which again is a measure of the tearing resistance.

\section{The Mill Stand and Its Work} (Continued srom page 359)

end of each platform. One of these tables inclines from the level of the rolling mill to a higher level at the right. At the extreme left of the picture there are heating furnaces, heated by oil, in which the steel ingots or slabs are brought to a red heat.

In operating, the white hot masses of solid steel are brought out of the heating furnaces at the left and mechanically placed on the long table adjacent thereto. This table can be brought in front of any set of furnaces in the plant because it travels electrically on the rails underneath. The hot steel is then transported in this platform up to the rolls by means of a set of small rolls or wheels which are visible on top of each platform. A slab of steel can be seen passing through the rolls and reaching the right hand inclined platform. From there it is also transported on rolls to the floor level on the right where it passes to other portions of the plant for further treatment. The two traveling platforms can thus operate on each side of any of the three or four sets of rolls in the center, and also in front of any of the heating furnaces at the left.-By $\boldsymbol{A}$. R. Surface.

\section{Exploiting the Inventor-I} Continued from page 360 )

search" and tell you in five minutes whether or not your patent can be obtained. He doesn't hold himself cheaply. He doesn't give you a piece of government paper with some words printed on it and call it a patent. He gets you a real patent which is as valuable as the invention it covers, or he doesn't get you any patent t all.

Inventors who want to have their inentions pay dividenids should realize first, that a patent is not necessarily valuable; one can only say that a patent which fully covers an invention may be as valuable as the invention. They should learn, second, that a valuable patent is seldom prepared or produced by a shyster whose only interest is his fee. The father who would take his child to the cheapest doctor may well take the child of his brain to the cheapest lawyer, but the parent with a heart gets a good doctor for his offspring and the inventor with a brain gets a good lawyer to obtain a good patent.

These are the law and the prophets both of success in the field of invention. A good patent is the foundation, and a good patent is seldom or never obtained save by a reputable and reliable firm. Make sure of the character of the attorney you employ .... it is a better guarantee of the quality of your patent than any advertisement ever published.

\section{Piercing New Zealand's Mountain} Barrier

(Continucd from page 363)

strike had occurred. At the Bealey end the progress has been very irregular, the work being idle for a year or more owing to the water difficulities.

As regards the completion of the tunnel, if a nother 100 men are obtained, thus enabling another shift to be put on at the Bealey end and two extra shifts at Otira end and more facilities given for coöperative contract work, the lining of the tunnel should be completed in less than two years. The main thing, however, is that when the lining is completed the material for electrification should be ready for installation, four schemes having been submitted to the Government.

Towards the end of October, 1919, the Minister of Public Works stated that at the Otira end all work during the year had been carried out by day labor. The bottom heading had been driven 691 feet and approximately 200 feet of this timbered. Slow progress had been made with the enlargement and lining, owing to the difficulty of obtaining suitable labor. At the Bealey end work for the first half of the year continued on the day labor system, but was changed to contract in September. The bottom heading was driven 413 feet, where it met the drive from the Otira end. The progress of enlargement was hampered for the same reason as at the Otira end.

From the Mountains of Montana to the Tetons of Wyoming

(Continued from page 364)

a view of Yellowstone Lake with the Tetons looming majestically fifty miles away.

Turning to the north we reach the Grand Canyon of the Yellowstone. The view from Artist Point on the eastern rim is the most comprehensive and satisfying
of all. Both walls of the Canyon are of all. Both walls of the Canyon are which is about twice the 'height of Niagara occupies the center. For three miles below the fall the rhyolite rock of the anyon has been colored by the fumes of hot springs. The effect is like a painting n water colors; yellows predominate with pinks and whites and rarer touches of crimson. In no way is it comparable with the rich coloring of the Grand Canyon of the Colorado, but it has a unique delicacy that is a delight to all lovers of
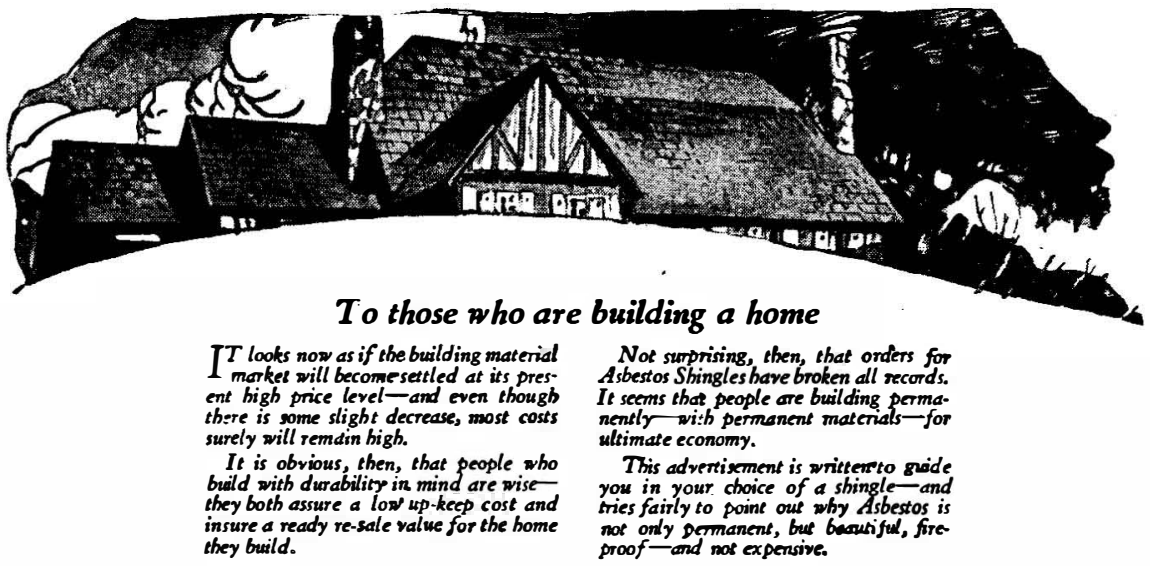

\section{Enemies of all good Shingles except Asbestos Shingles}

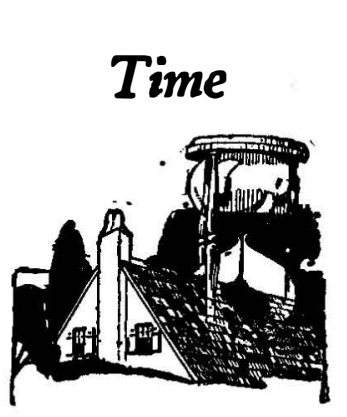

THERE is an obvious reason for the fact that Asbestos
Shingles do not deteriorate either in strength or beauty as time goes on.

For there is nothing about Asbestos Shingles that is subject to change. Their strength is permanently high-not varying or diminishing due to the gradual loss or alteration of some ingredient. They are always hard and tough - not soft in summer and brittle in winter. They retain their shape and beauty without warping, peeling or curling, for shape and beauty without warping, peeling or curting

All of this because Asbestos is a mineral-one that has endured for ages unaltered in its remerkable characteristics, and Asbestos fibres, consinied with Portland cement, make shingles of stone whose life can be measured only by asking "How long will the building last?"

"As a matter of fact, Johns-Minvillo Asbostos Shingleo actually
Weather

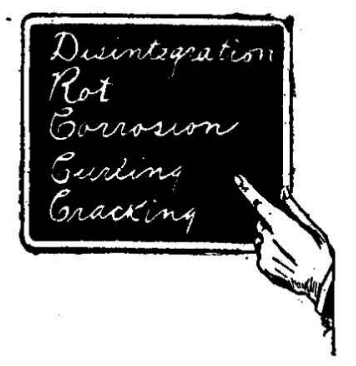

A LL good shingles resist' weather as long as they lest, winter and the heat of summer. Atmospheric action is the wint and the heat of summ is mist core to the air, regardless of climatic conditions.

Some air contains gases that are very destructive-all air has in it the power to destroy organic matter within the space of a few years.

But atmospheric action is not an enemy of Johns. Manville Asbestos Shingles, because they are all-mineral. They cannot rot, for only organic matter provides the food for the gerass of decay. They cannot corrode, even where exposed to most acid fumes.

They do not disintegrate, because the strong fibres of Asbestos, acting as permanent, tough binders, are not weakened by exposure.

MANY good organic shingles have a coating of some is ample protection if the coating is applied thick enough, is ample protection if the coating is applied thick enough,
without the use of an inflammable adhesive-and if it stayo on permanently.

Fire

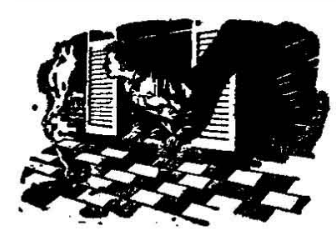

Do not expect to find a coating on Johns-Manville Asbestos Shingles - they are not coated, but uniform in structure. Ther contain no combustible saturants or organic materials of any sort, which explains why they are fireproof even when the blazing brands of an adjacent fire fall on them. They are just what you would expect from an all-mineral material.

Because of these facts, those who make insurance rating give Johns-Manville Asbestos Shingles the highest classification for fire-safety.

Johns-Manville Asbestos Roofings include Asbestos Roll Roofing, Johns-Manville Standard and Colorblende Asbestos Shingles, Johns-Manville Asbestos Ready Roofing, JohnsManville Corrugated Asbestos Roofing, Johns-Manvilla Built-Up Asbestos Roofing.

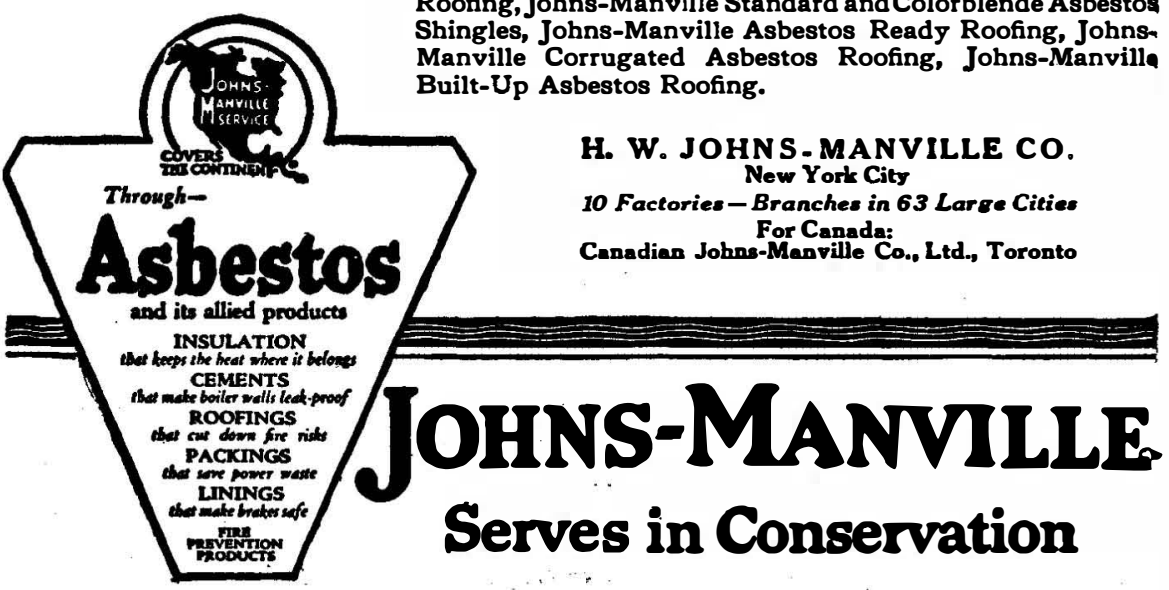




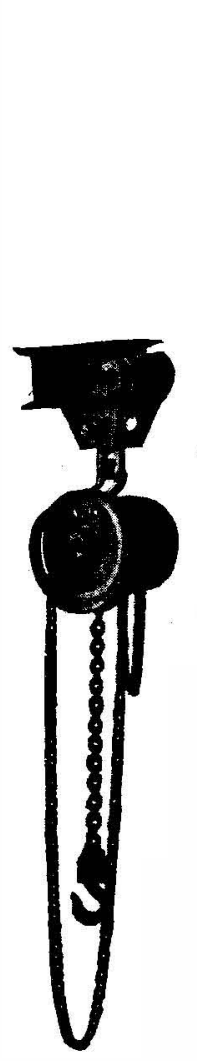

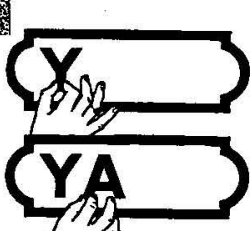

"Good-by Strong Arm Methods"

Says the Superintenden

THE old way required a gang taken away

from other work. The Yale Spur-geared

Chain Block, and one man, now do the

hoisting Quicker, Safer, and with Economy.

Yale Chain Blocks help solve production problems, eliminating slow, dangerous "strong arm" methods that decrease output.

Executives responsible for plant production economy and safety will find constructive information in the new Yale Chain Block Catalog. Send for it.

"From-Hook-to-Hook-a-line-of-Steel"

For a Faclory Locking Equipmen

The Yale \& Towne Mfg. Co. Makers of the Yale Lock

Connecticut

Stamford

\section{SONNEBORN PRODUCTS}

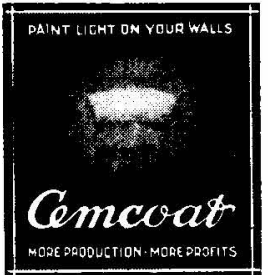

$\mathrm{H}$ IGH wages and shortened hours for labor now make it IMPERATIVE to have every workroom well lighted.

Cemcoat is the glossy, mirror-like wall coating which increases the natural or artificial light by reflecting it from every angle.

And this increased light is so diffused that there are no nerve-racking, profit-killing contrasts of bright spots and hard shadows.

It costs less to increase light by the Cemcoat system than by cutting more windows or installing more lights. Furthermore, Cemcoat is more economical in the long run than commercial white paints, because it is durable, washable and does not peel or crack.

SONNEBORN PRODUCTS LAPIDOLTH - the liquid chemical
hardener, makes old or new concrete hardener, makes old or new co
floors dustrpool and wearproof.
lat LLGNOPHOL-the weadern wood pre
servative, gives new life to old or new servative, gives new life to old or new
WToden hoors
STORMTIGHT-the protective roof
coating coating for all kinds of worm or new
roofs saves labor and material cost
of new roofs. SONNEBORN beauty. In the early morning I have Along its forested shores there is a wide watched its colors gradually awaken un- margin of deep mud and of utter forest til the sun turned backward the curtain devastation. of Little clouds of mist fioat upward from the fall and vapor rises from the hot springs along the edge of the river. $\mathrm{Be}$ neath the forest which peers over the rim are cliffs of yellow and orange: across the canyon the upper well is chalky white. Pines and spruces are scattered among the innumerable multitude of fretted and varicolored pinnacles which adorn the slopes; while the river is deep green and foamy white where there are rapids. Resting over all is the soft blue of the sky. Ospreys sail back and forth through the canyon, now and then alighting on some inaccessible pinnacle where their young are nesting. In the contemplation of a scene so vast and beautiful the soul demands appropriate silence that it may hear the music of nature. In former years I have found the canyon secluded from irreverent noise, but now no spot remains where one may escape the incessant shrill exhaust whistles of automobiles. For several hours a day and into the night their irritating sound crosses from either side. Some day we hope it may be possible to arrange for rapid transportation in a manner more in keeping with the grandeur and peace of the canyon. Among many other points one should visit Inspiration on the opposite rim Its view is less symmetrical than that from Artist Point, and it lacks the ful view of the great fall, but the wild grandeur of the canyon is more apparent.

Descending the ravine near the Lower Fall at sunset, we reached the river. Clouds of rainbowed spray sweep out from the fall upon the slopes where the mosses gather, and trickle back to the river. Looking up we saw an osprey, laden with twigs for its nest, fiying close to the glassy green brink of the fall. On one side the water plunges white and one side the water plunges white and
heavy, throwing itself outward upon a concealed rock; on the other it shoots downward in misty comets like soft silken floss. Following down the river until the walls became impassable, we found tiny hot water geysers with brown and green and white on their cones.

The nearby crumbling rock ranges in color from white to carmine. Years ago I climbed from this point directly up the treacherous slope of the canyon to the rim, which is about 1200 feet in height, but the temptation to slip back was very strong. Looking up from the river at sunset the cathedral crags are lit with joyous color. Peering into the depths of the canyon at night it is devoid of color lying ghostly white in the moonlight.

From the summit of Mt. Washburn, 10,000 feet in height, which we reached in an auto, there is a comprehensive view of park-like forests and of many mountains on the horizon. The Yellowstone is a dying geyser field which is slowly turning into hot springs and pools of great beauty. After visiting the most interesting formations and geysers of the park, we left Old Faithful by auto for Moran to the south. Passing through a heavily wooded country of high elevation we looked down on Shoshone Lake and had a distant view of the Teton Range which we were to reach that evening. At the paused to view the Paint Pots with their bubbling mixture resembling rose colored calcimine, and a little geyser playing on calcimine, and a little geyser playing on
the very edge of the lake. Turning south the road follows the shore of Lewis Lake, and then along Lewis River past colorful meadows and sparkling streams to the crooked Snake. We had near glimpses of deer, of elk, and of moose. Finally we reached the long valley of Jackson Lake which has been dammed at its southern outlet to control the waters of the Snake River for the benefit of Idaho lands. The water was low in the lake and for mines
the dead trees created a gloomy landscape. devastation. In turning a lake into a reservoir of larger area it is important hat the standing trees be cut along the shore, and not be left to their death by water. Alas, the beauty of Jackson Lake has been unnecessarily ruined for years to come. On its shores and islands is a dense and muddy tangle of standing and fallen timber. Once a paradise for count ess water fowl, the varying water levels have worked utter ruination. Even the birds and the animals desert its shores in disgust. From the slopes of the mountains one looks down upon ruined areas where the water has found its way inland, and, in traveling across country, one is unhappily confronted by these dismal swamps with their foul odor of decay. From Moran there is a glorious view of the Tetons rising six to seven thousand feet above the western shores of Jackson, Leigh and Jenny Lakes. From Mount Moran, 11,100 feet in height, to far beyond the Grand Teton, 13,747 feet, in the south, rugged canyons alternate with unclimbed peaks that await the mountaineer. Some day a trail will follow the eastern shore of Leigh Lake and one of the most exquisitely beautiful views in America will be enjoyed by many. But it is proposed to make reservoirs of Leigh and Jenny Lakes, raising their level and ruining their charm. Each lake is only about two miles in length, although their corresponding shore lines are much longer. We do not question that it is desirable to increase our facilities for irrigation but we ask if America cannot well afford to preserve these little lakes from ruination? They are among her most precious gems. It is even rumored that a movement is now quietly on foot to use Yellowstone Lake itself for irrigation purposes We cannot believe that the thousand who have seen and loved its natural charms will enjoy the thought of the consequences. Let them visit Jackson Lake if they desire information.

It is proposed that 1,000 square miles of fine scenery, including the headwaters of the Yellowstone with the Teton Range, be added to Yellowstone Park. As these mountains are unique in their wild and rugged grandeur, they will form a fitting climax to the wonders of the park and will afford a splendid field for the mountaineer for many a day to come.

\section{From Boneyard to Shipyard} (Continued from page 366)

spends itself. At the narrow inlet of the harbor some of its force may be felt; t is not here, however, that the shipyards are situated, but from three to five miles inland. This island of Alameda is ngs, trolley lines, electric railnoad lines, it offers protection to the inner harbor from the winds that pour through the Golden Gate, that is not of slight consider ation.

Favorable climatic conditions are very important in the building, launching and fitting-out of ships. The work of building is much exposed to the weather therefore the better the surrounding weather conditions are the greater is the work facilitated. Calm waters and tempered winds are also important in the they lay moored at the fitting-out wharves. All these considerations were carefully weighed in deciding upon Oakland's inner harbor as a spot well fitted to the strenuous work in hand.

Through Oakland's inner harbor has ebbed and flowed the city's marine indusry. During the fiscal year ending June 30 th, 1918, vessels to the number of 51,142 , and of a net register of tonnage of 2,624 172 tons arrived, bringing 853,811 tons of cargo. However, by reason of its protected waters, ample length and proximity to the port of San Francisco, it had for years been the dumping ground of marine derelicts, the anchorage of. vessels. temlow and fiat yet with all its many buildfitting out and finishing of the vessels as 


\section{The Artist's Bracket} Fungus

URING the winter when most of the tree are bare, the queer corky or wooly. growths known as wacket fungi stand out rather conspicuously on liseased trunks, logs, and stumps. The largest and best known of these in our northern moods is the artist's bracket fungus, so called because it is frequenta displayed in frequent19 displayed in summer camps with sketches more or less crude etche upon its iwhite under surface.

The upper surface is flat or slightly arched, gray or brown in color, and almost us hard and smooth as horn. When cut or broken open, the layers of growth produced each year may be

seen and the age of the bracket determined. The small tubes developed annually on the lower surface contain the soores, which are distributed far and wide by the wind and carry the fungus to other trees.

These spores are very minute and require a wounded or decayed spot for their germination and early derelopment, but when the delicate branching threads a rising from the spores have once become established they permeate the trunk in all directions seeking food und destroying the tissues in order to obtain it.

The development within the trunk may continue several years before the brackets, or fruiting bodies, appear on the outside of the tree. Once within the trunk, however, the fungus cann'ot possibly be reached and destroyed, although the destruction of the brackets will, of course, lessen the number of spores that are produced and blown to other trees.

But there is little chance of escape for any tree having a wound or decayed spot, since the number of spores produced is so enormous as practically to fill the entire forest with spore-dust day and night from early May to late October. A single bracket of this fungus liberates into the air about 30,000 million sporas in 24 hours, and a single trunk may bear from 10 to 60 brackets, all dischiarging spores at once during the entire growing season and reviving year after year with even greater activity and a larger output of spores. This species probably holds the record among fungi for spore production.-By W. A. Murrill.

\section{Nightly Cooling of Lower Strata of the Atmosphere}

THE chief cause of the cooling at night of the lower 1 layers of the atmosphere is radiation from the dust particles suspended. To this the formation of temperature inversions near the surface is to be attributed. Most of the heat is radiated into space; the amount radiated to the surface of the earth is about $1 / 3$ of this. The conclusion seems to be well supported. (Albert Defant, Annalen der Hydrographic und Maritimen IIcteorologie, Part V./VI., 10:9.)

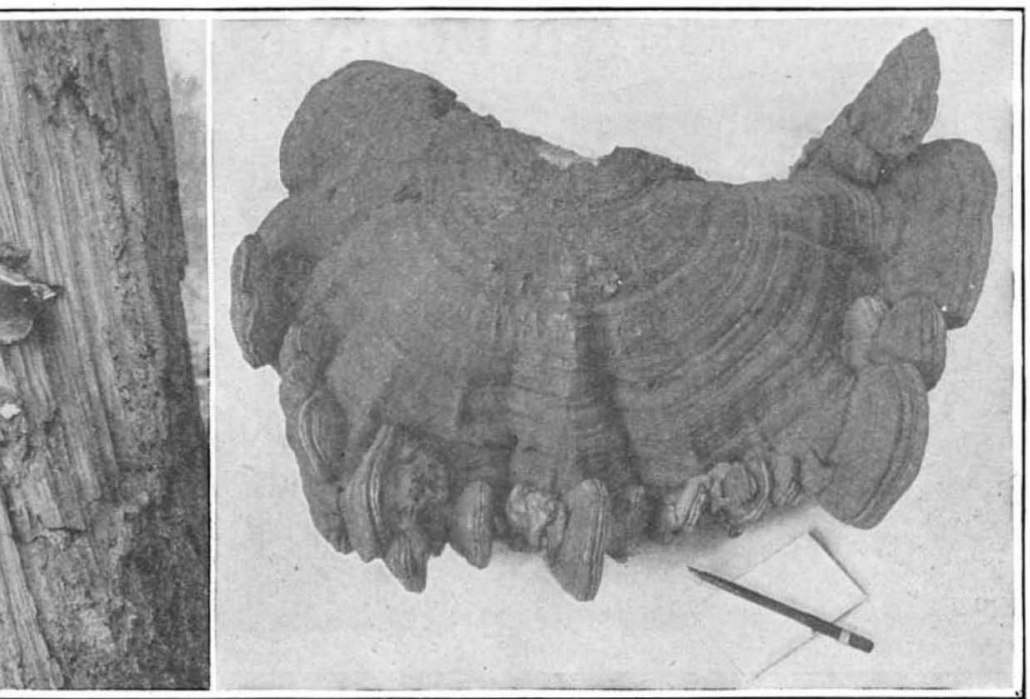

26 inches across and weighing 40 pounds

The Forefather of the Motion Picture

UST who is the father of the motion picture is $\int$ matter of bitter controversy in which Americans and Europeans are equally keen to enter. But when it comes to contesting the title of forefather of the "movies," the atmosphere is relatively quiet.

So we proceed to nominate the sharlow pictures and puppets of ancient Java, recently presented to the United States Museum by the King of Siam, as the forefather of our present-day photoplays. The pic-

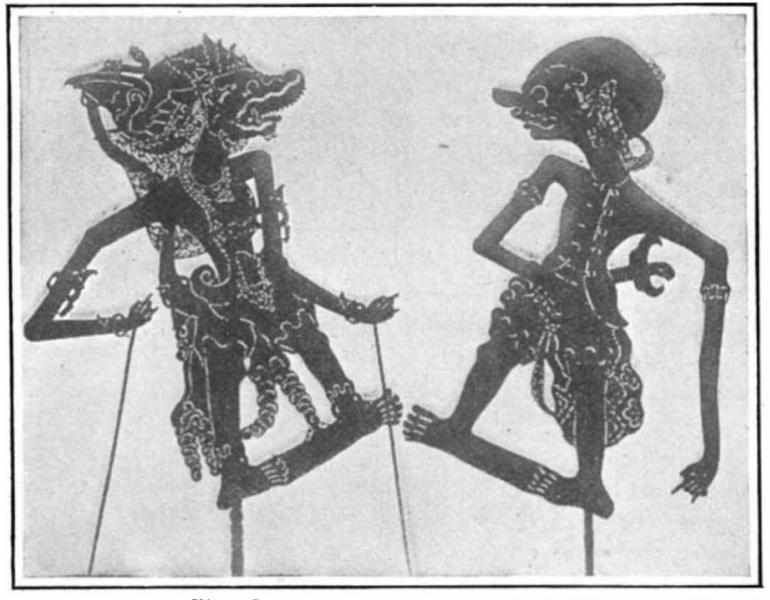

Javanese puppets used for animated shadow-pictures

tures, in those lark lays before the dawn of written history, were thrown on a screen and moved back and forth hefore the Javanese audience as the exhibitor told the story. The puppets were cut from deer hide, and considerable skill was obviously required to do this work. Some of the more elaborate puppets were animated by strings, as in the case of the one at the left in the illustration.-By Alfred Mayfield.
The Traveling Sand

\section{Dunes of Peru}

$A \mathrm{~S}$ one makes the ascent of the Andes from the Pacific port of Mollendo Peru, following the line of the Southern of Peru Railway, the climb to the divide is broken by two great steps or wide-spreading shelves of desert or pampa.

On the first of these steps, about two inours' steep climb from the sea, and at an altitude of from 4,000 to 5,000 feet, are located the famous drifting sand hills of Peru. The plateau is here about twenty miles wide, the air thin and dry and no trace of vegetation to be seen, only these giganti.c crescent-shaped sand dunes dotting the pampa as far as the eye can see. Composed of fine gray crystal sand, they gleam white against the brown of the desent, and their horns poin toward the prevailing south wind of this region. They are from fifteen to twenty-five or even thirty feet high, twenty feet in breadth across the thick part of the crescent and sometimes one hundred feet from horn to horn. So tightly is the sand packed that the feet of the horses or mules make little impression on it.

These sand hills, alled medaños (pronounced má-dlań-yos,-possibly a Latinized form of dunes) travel with almost imperceptible slowness, and when they threaten the railway track they can sometimes be divented by piling up bilocks of stone in their paths Otherwise the railway bed has to be altered to go around them. An analysis of the soil of this region shows that it would be very fertile if irrigated from the available snow-fields of the Andes, so that it is possible there will come a day when its desolate dunes will cease to be.-By G. E. McDonald.

\section{Simple Way of Killing a Weed} STRONG growing weeds with elaborate roots are $S$ often difficult to kill. Sometimes they cannot be lifted without doing damage to adjoining plants; yet to cut off the surface foliage and leave the roots in the ground is no good at all. After this the weed frequently grows more vigorously than ever.

Any weed may be killed in this way. Cut off the top growth down to the ground. Then scoop out the central stalk as much as possible and fill the little cavity with salt. If possible, do this in dry weather. When rain occurs and the salt dissolves, quickly place a fresh amount on the root. At the end of three days (if the salt has not been washed away) it will have penetrated to every part of the root and the weed will never give any more trouble. Weeds with roots a foot deep have been lifted after this treatment when it has been found that the whole underground system of the plant was brown and rotten right to the tips.-By S. Leonard Bastin.

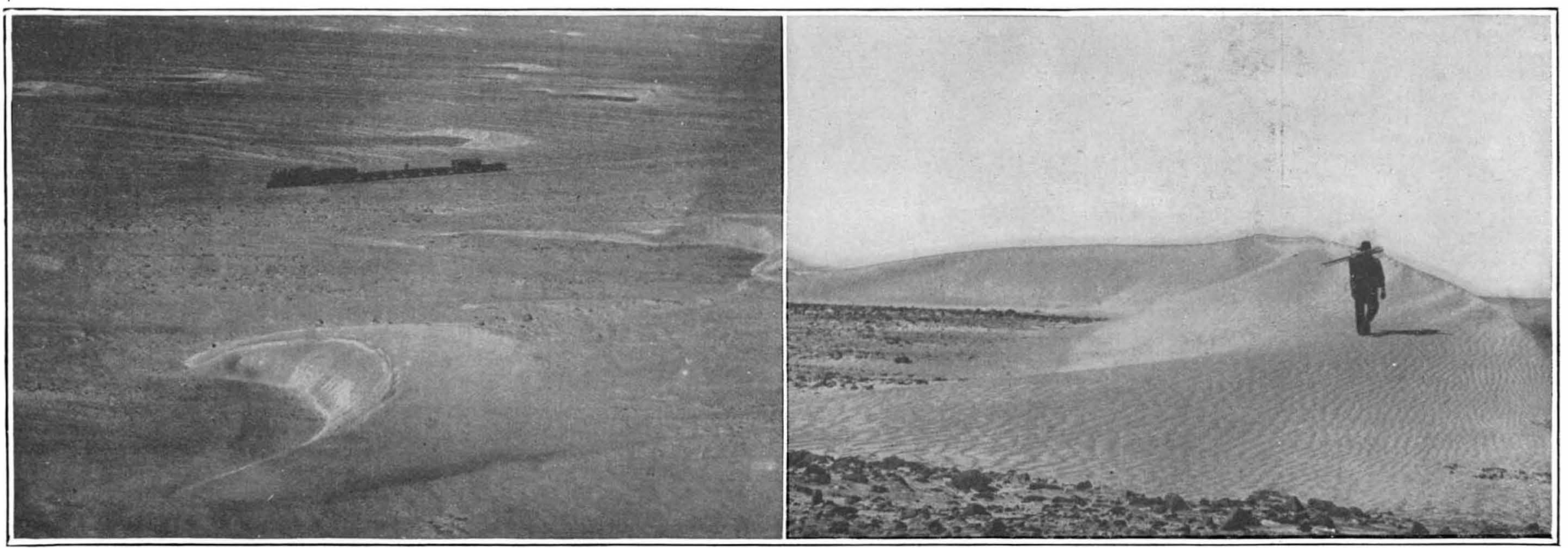

Huge crescent formed by the white sand on the gray of the desert plateau of Peru Near view of one of these bizarre crescents measuring 25 to 30 feet high
and 100 feet wide 